\title{
Efficiency of Investments in Regional Airports in Poland 1
}

Aleksandra GÓRECKA (https://orcid.org/0000-0002-2679-561X), Department of Economics and Organisation of Enterprises, Warsaw University of Life Sciences, Poland; e-mail: aleksandra_gorecka@sggw.pl

Joanna BARAN (https://orcid.org/0000-0001-9801-4344), Department of Logistics, Warsaw University of Life Sciences, Poland; e-mail: joanna_baran@sggw.pl

\section{Polonya'da Bölgesel Düzeydeki Özel Havalimanı Yatırımlarının Etkinliği²}

\begin{abstract}
The article, based on the Data Envelopment Analysis (DEA) method, determined the efficiency of investments from the period of 2007-2013 in individual Polish airports. The applied DEA model was aimed at maximizing effects. The following variables were adopted in the model: 1 input (the total value of funds allocated for investments in 2007-2013) and 5 effects (increase in the number of passengers served, increase in airport operations (ATM), increase in the number of parking aprons, increase in the number of direct regular destinations, increase in the number of gates). 6 airports showed the efficiency of the investments. For other airports, according to the benchmarking idea, changes in the level of effects were proposed that could improve their efficiency.

Keywords $\quad$ : Airport, Efficiency, Data Envelopment Analysis, EU Funds.

JEL Classification Codes : R11, R15, R40.

\section{$\ddot{\mathbf{O} z}$}

Bu çalışmada, Veri Zarflama Analizi kullanılarak, Polonya'da 2007-2013 yılları arasında bölgesel düzeydeki özel havalimanı yatırımlarının etkinliği ölçülmeye çalışılmıştır. Veri zarflama analizi etkilerin maksimize edilmesini amaçlamaktadır. Girdi olarak 2007-2013 yılları arasında yatırımlara ayrılan tutar ele alınmış ve etkisi ölçülecek çıktılar olarak da yolcu sayısındaki artış, haavalimanı hizmetlerindeki artış, apron sayısındaki artış, doğrudan düzenli uçuş yapılan destinasyonlardaki artış ve uçuş kapılarındaki artış olmak üzere beş değişken belirlenmiştir. Sonuç olarak altı havalimanı yatırımlar açısından etkin olarak bulunmuştur. Diğer havalimanları ise karşılaştırmalı olarak etkinliklerini artırmaya yönelik düzenlemeler yapmak durumundadırlar.
\end{abstract}

Anahtar Sözcükler $\quad$ : Havaliman1, Etkinlik, Veri Zarflama Analizi, AB Fonları.

1 This article is the revised and extended version of the paper presented in " $4^{\text {th }}$ International Annual Meeting of Sosyoekonomi Society" which was held by Sosyoekonomi Society and CMEE - Center for Market Economics and Entrepreneurship of Hacettepe University, in Vienna/Austria, on October 27-28, 2017.

Bu makale Sosyoekonomi Derneği ile Hacettepe Üniversitesi Piyasa Ekonomisini ve Girişimciliği Geliştirme Merkezi tarafindan Avusturya'nın Viyana şehrinde, 27-28 Ekim 2017 tarihlerinde düzenlenen "Dördüncü Uluslararası Sosyoekonomi Derneği Yıllık Buluşması”nda sunulan çalışmanın gözden geçirilmiş ve genişletilmiş halidir. 


\section{Introduction}

In 2017, it has been 13 years since Poland became a member state of the European Union. Since 2004, the country has had full access to EU funds to support the modernization of most sectors of the economy. In the period of 2004-2013, from the point of view of economic development, Poland used two basic funds, that is, The European Regional Development Fund and the Cohesion Fund ${ }^{3}$.

The development of the transport sector, especially of the infrastructure, was one of the most strategic areas that needed to be modernized. Poland's transport infrastructure after 1991 drastically collapsed, and in a young democratic country, the government was unable to meet the needs of modernizing existing infrastructure or making new investments in this area. It was known, however, that transport infrastructure is an important part of the social life and economic situation of the regions. Its structure and scope determine the mobility of the inhabitants, the potential of the area for settlement, and, from the point of view of entrepreneurship development, the possibility of locating companies or conducting commercial cooperation (Górecka, 2015). The construction and maintenance of transport infrastructure are highly cost-consuming and often represent a significant financial resource for the government or self-government units. Therefore, EU subsidies have proven to be invaluable support for the country's infrastructure's redevelopment. Four years after the completion of the second aid program, the efficiency of the use of EU funds for the modernization of transport infrastructure can be summarized and assessed.

\section{Methodology of Research}

The aim of this article is to assess the efficiency of investments (including the use of EU co-financing) in the construction or modernization of regional airports in Poland and to establish a ranking of regional airports in Poland according to the efficiency of investments made in 2007-2013. The research covered all regional airports in Poland (i.e. excluding Warsaw Chopin Airport) which benefited from European Union funding for the construction or modernization of airports in 2004-2013 - a total of 12 facilities (Fig.1). 


\section{Figure: 1}

\section{Airports in Poland (as on 12 January 2016)}

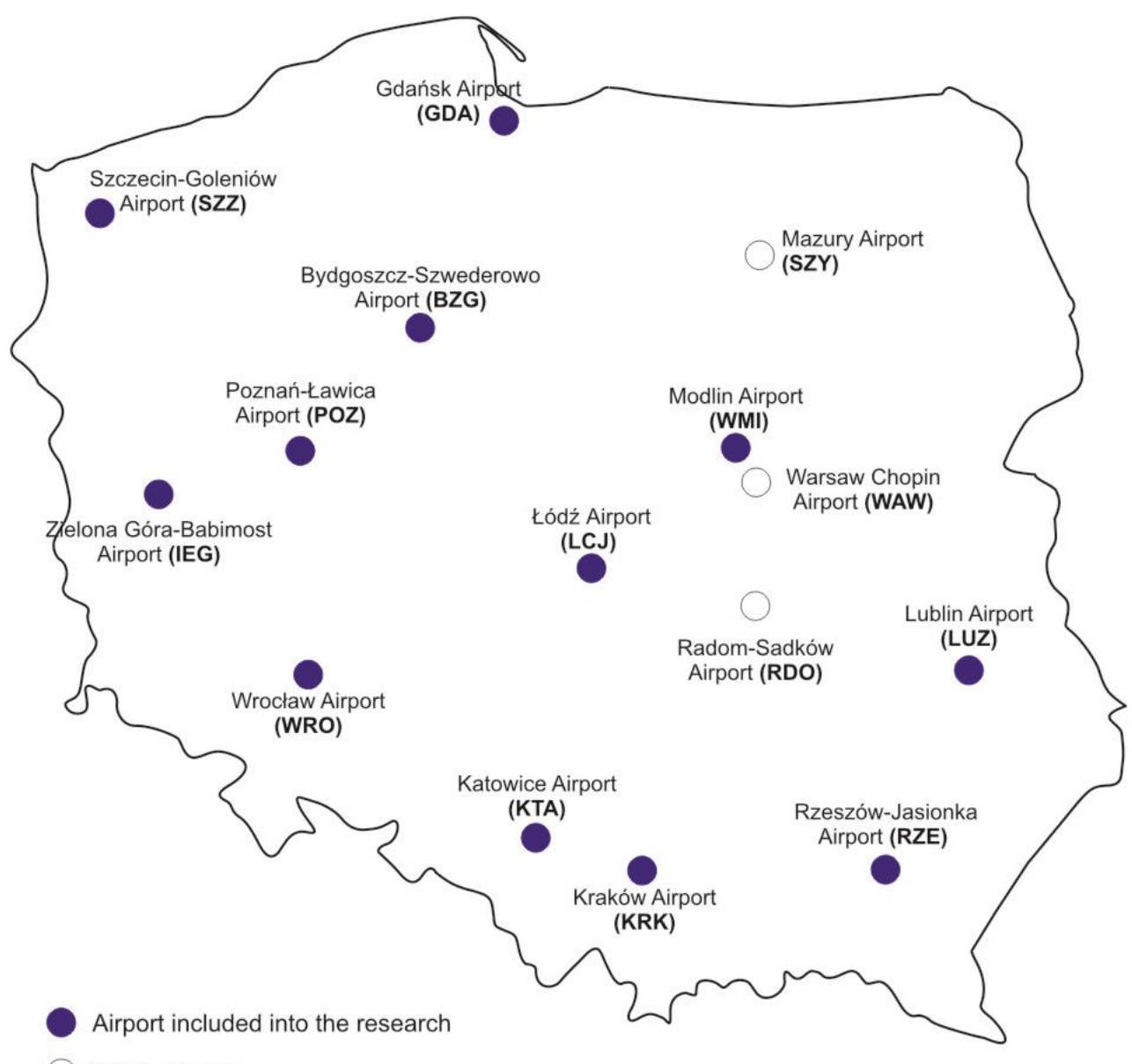

Other airports

Source: Own elaboration.

The assessment of the efficiency of the investments made in Polish airports will be conducted using the Data Envelopment Analysis (DEA) method. We used secondary data sources including Polish Civil Aviation Authority database for indexes on aviation, terminal constructions, and passengers number and National Information System (KSI SIMIK 07-13) for searching for data on EU founding in airport infrastructure in Poland. 


\section{Literature Review}

The DEA method is widely used throughout the world in airport performance research. Data Envelopment Analysis (DEA) is a non-parametric mathematical programming approach for measuring relative efficiencies of comparable DMUs (Decision Making Units) with respect to multiple inputs and outputs (Charnes et al, 1978). The DEA models may be categorized based on two criteria: model orientation and type of returns to scale. Depending on the model orientation a calculation is made of technical efficiency focused on the input minimization or of technical efficiency focused on the output maximization. But taking into account the type of returns to scale the following models are distinguished: the CCR model providing for constant returns to scale (the name derives from the authors of the model: Charnes-Cooper-Rhodes (Charnes et al, 1978)) and the BCC model providing for changing return to scale (the name derives from the authors of the model: Banker-Charnes-Cooper (Banker et al, 1984)). The CCR model is used to calculate the overall technical efficiency (Technical Efficiency - TE) and the BCC model is used to calculate pure technical efficiency (Pure Technical Efficiency - PTE).

\subsection{CCR-Model}

Charnes, Cooper and Rhodes (Charnes et al, 1978) introduced a measure of efficiency for each DMU that is obtained as a maximum of a ratio of weighted outputs to weighted inputs. The weights for the ratio are determined by a restriction that the similar ratios for every DMU have to be less than or equal to unity, thus reducing multiple inputs and outputs to single "virtual" input and single "virtual" output without requiring preassigned weights. The efficiency measure is then a function of weights of the "virtual" input-output combination. Formally the efficiency measure for the $\mathrm{DMU}_{\mathrm{o}}$ can be calculated by solving the following mathematical programming problem (Cooper et al. 2007):

$$
\max _{u, v} h_{0}(u, v)=\frac{\sum_{r=1}^{s} u_{r} y_{r 0}}{\sum_{i=1}^{m} v_{i} x_{i 0}}
$$

subject to

$$
\begin{aligned}
& \frac{\sum_{\mathrm{r}=1}^{\mathrm{s}} \mathrm{u}_{\mathrm{r}} \mathrm{y}_{\mathrm{rj}}}{\sum_{\mathrm{i}=1}^{\mathrm{m}} \mathrm{V}_{\mathrm{i}} \mathrm{x}_{\mathrm{ij}}} \leq 1 \quad\left(\mathrm{j}=1,2, \ldots, \mathrm{j}_{0}, \ldots, \mathrm{n}\right) \\
& \mathrm{u}_{\mathrm{r}}, \mathrm{v}_{\mathrm{i}} \geq 0 ; \quad r=1,2, \ldots, s ; \mathrm{i}=1,2, \ldots, m
\end{aligned}
$$

where: 
$x_{i j}$ - the observed amount of input of the $i_{\text {th }}$ type of the $j_{\text {th }} \operatorname{DMU}\left(x_{i j}>0, i=1,2, \ldots, n, j=1,2\right.$, $\ldots, n)$

$y_{r j}$ - the observed amount of output of the $r_{\text {th }}$ type for the $j_{\text {th }} \operatorname{DMU}\left(y_{r j}>0, \mathrm{r}=1,2, \ldots, s, j=1\right.$, $2, \ldots, n)$.

The variables $u_{r}$ and $v_{r}$ are the weights to be determined by the above programming problem. However, this problem has infinite number of solutions since if $\left(u^{*}, v^{*}\right)$ is optimal then for each positive scalar $\alpha\left(\alpha \mathrm{u}^{*}, \alpha \mathrm{v}^{*}\right)$ is also optimal. Following the Charnes-Cooper transformation, one can select a representative solution $(u, v)$ for which

$$
\sum_{i=1}^{n} v_{i} x_{i o}=1
$$

to obtain a linear programming problem that is equivalent to the linear fractional programming problem (1) - (4). The problem (5) - (8) is so-called "input-oriented CCR model", in which the maximization is oriented toward the choice of "virtual multipliers" (i.e. weights) $u$ and $v$ which produces the greatest rate of "virtual output" per unit of "virtual input". Thus, denominator in the above efficiency measure $h_{o}$ is set to equal one and the transformed linear problem for $\mathrm{DMU}_{0}$ can be written:

$$
\max _{\mathrm{u}} \mathrm{z}_{0}=\sum_{\mathrm{r}=1}^{\mathrm{s}} \mathrm{u}_{\mathrm{r}} \mathrm{y}_{\mathrm{ro}}
$$

subject to

$$
\begin{aligned}
& \sum_{\mathrm{r}=1}^{\mathrm{s}} \mathrm{u}_{\mathrm{r}} \mathrm{y}_{\mathrm{rj}} \quad \sum_{\mathrm{i}=1}^{\mathrm{m}} \mathrm{v}_{\mathrm{i}} \mathrm{x}_{\mathrm{ij}} \leq 0, \quad \mathrm{j}=1,2, \ldots, \mathrm{n} \\
& \sum_{\mathrm{i}=1}^{\mathrm{n}} \mathrm{v}_{\mathrm{i}} \mathrm{x}_{\mathrm{io}}=1 \\
& \mathrm{u}_{\mathrm{r}}, \mathrm{v}_{\mathrm{i}} \geq 0 ; \quad r=1,2, \ldots, s ; I=1,2, \ldots, m
\end{aligned}
$$

For the above linear programming problem, the dual can be written as:

$$
\min _{\lambda} \mathrm{z}_{\mathrm{o}}=\Theta_{0}
$$

subject to

$$
\sum_{j=1}^{n} \lambda_{j} y_{r j} \geq y_{r 0}, \quad r=1,2, \ldots, s
$$




$$
\begin{aligned}
& \Theta_{0} x_{i 0} \quad \sum_{j=1}^{n} \lambda_{j} x_{i j} \geq 0, \quad i=1,2, \ldots, m \\
& \lambda_{j} \geq 0, \quad j=1,2, \ldots, n
\end{aligned}
$$

The value of $\Theta$ is the technical efficiency score for the particular $\mathrm{DMU}_{0}$. The value of $\Theta$ is always less then or equal unity. DMUs for which $\Theta<1$ are relatively inefficient and those for which $\Theta=1$ are relatively efficient, having their virtual input-output combination points lying on the frontier. The frontier itself consists of linear facets spanned by efficient units of the data, and the resulting frontier production function (obtained with the implicit constant returns-to-scale assumption) has no unknown parameters.

\subsection{BCC-Model}

Banker et al. (23) extended the earlier work of Charnes at al. (Charnes et al, 1978) by providing for variable returns of scale and thus mitigates the impact of economies of scale on operational efficiency. The BCC model adds an additional variable $u_{0}$ to identify the returns of scale of the target DMU. The input-oriented BCC-model for the $\mathrm{DMU}_{0}$ can be written formally as (Cooper et al. 2007):

$$
\min _{\lambda} Z_{o}=\Theta_{0}
$$

subject to

$$
\begin{aligned}
& \sum_{j=1}^{n} \lambda_{\mathrm{j}} \mathrm{y}_{\mathrm{rj}} \geq \mathrm{y}_{\mathrm{r} 0}, \quad \mathrm{r}=1,2, \ldots, \mathrm{s} \\
& \Theta_{0} x_{i 0}-\sum_{j=1}^{n} \lambda_{j} x_{i j} \geq 0, \quad i=1,2, \ldots, m \\
& \sum_{j=1}^{n} \lambda_{j}=1 \\
& \lambda_{j} \geq 0, \quad j=1,2, \ldots, n
\end{aligned}
$$

The BCC-efficiency scores have similar interpretation as in the CCR model. With the overall technical efficiency and pure technical efficiency calculated, it is possible to determine the object scale efficiency (Scale Efficiency - SE). The scale efficiency is defined as a ratio of DMUs overall technical efficiency score (measured by the CCR-model) and pure technical efficiency score (measured by the BCC model), according to the formula: SE $=$ TE/PTE (Coelli et al., 2005). Scale efficiency (SE) calculated in this manner denotes the 
degree to which the object is efficient in relation to the optimum enabling the maximal use of inputs. A review of the research studies using the DEA method is shown in Table 1.

Table: 1

Use of the DEA Method in Performance Studies in Airports - Literature Review

\begin{tabular}{|c|c|c|c|}
\hline Author & Observations & Inputs & Outputs \\
\hline $\begin{array}{l}\text { Parker } \\
(1999)\end{array}$ & $\begin{array}{l}22 \text { British BAA airports } \\
\text { before }(1979 / 80) \text { and } \\
\text { after privatization }(1995 / 96)\end{array}$ & $\begin{array}{l}\text { - number of employees } \\
\text { - cost of capital } \\
\text { - operating costs }\end{array}$ & $\begin{array}{l}\text { - number of passengers (PAX), } \\
\text { - the volume of cargo transportation. }\end{array}$ \\
\hline $\begin{array}{l}\text { Gillen and Lall } \\
\text { (1997) }\end{array}$ & $\begin{array}{l}21 \text { US airports } \\
\text { in } 1989-1992\end{array}$ & $\begin{array}{l}\text { - number of runways, } \\
\text { - number of gates, } \\
\text { - terminal area, } \\
\text { - number of employees, } \\
\text { - number of baggage claim areas, } \\
\text { - number of parking spaces, }\end{array}$ & $\begin{array}{l}\text { - PAX, } \\
\text { - ATM, } \\
\text { - number of handling operations at the airport }\end{array}$ \\
\hline $\begin{array}{l}\text { Martín and Román } \\
(2001)\end{array}$ & $\begin{array}{l}\text { Cost effectiveness of } \\
\text { Spanish airports in } 1997\end{array}$ & $\begin{array}{l}\text { - labour cost } \\
\text { - cost of capital } \\
\text { - cost of materials }\end{array}$ & $\begin{array}{l}\text { - PAX, } \\
\text { - cargo, } \\
\text { - number of airport operations (ATM). }\end{array}$ \\
\hline $\begin{array}{l}\text { Pacecho and Fernandes } \\
(2002) \text { and (2003) }\end{array}$ & $\begin{array}{l}35 \text { Brazilian airports } \\
\text { in } 1998\end{array}$ & $\begin{array}{l}\text { - the surface of the airport apron, } \\
\text { departure areas, baggage claim areas, } \\
\text { - number of check-in counters, } \\
\text { - Number of parking spaces } \\
\text { - number of employees, } \\
\text { - wages fund, } \\
\text { - operating expense. }\end{array}$ & $\begin{array}{l}\text { - PAX } \\
\text { - cargo, } \\
\text { - operating income, } \\
\text { - other income. }\end{array}$ \\
\hline Vogel (2004) & $\begin{array}{l}35 \text { European airports } \\
\text { in the period of } 1990-2000\end{array}$ & - total cost of airport activity & $\begin{array}{l}\text { - total revenue, } \\
\text { - passenger terminal capacity, } \\
\text { - cargo terminal capacity. }\end{array}$ \\
\hline $\begin{array}{l}\text { Yoshida and Fujimoto } \\
\text { (2004) }\end{array}$ & $\begin{array}{l}\text { 37 Japanese airports } \\
\text { in } 2000\end{array}$ & $\begin{array}{l}\text { - length of runways, } \\
\text { - terminal area, } \\
\text { - internal transport costs } \\
\text { - number of employees } \\
\end{array}$ & $\begin{array}{l}\text { - density of passengers, } \\
\text { - number of transported loads, } \\
\text { - number of activities related to flights. }\end{array}$ \\
\hline $\begin{array}{l}\text { Abdesakena, Chen and } \\
\text { Cullman (2006) }\end{array}$ & $\begin{array}{l}17 \text { German airports } \\
\text { in 1998-2004 }\end{array}$ & - including total costs per $1 \mathrm{WLU}$ & $\begin{array}{l}\text { - including number of passengers per gate, } \\
\text { - number of flights per } 1 \text { airstrip. }\end{array}$ \\
\hline $\begin{array}{l}\text { Augustyniak } \\
(2014)\end{array}$ & $\begin{array}{l}19 \text { selected airports } \\
\text { in the European Union }\end{array}$ & $\begin{array}{l}\text { - employment cost, } \\
\text { - capital / investment costs, } \\
\text { - number of employees, } \\
\text { - number of gates, } \\
\text { - airport area, } \\
\text { - number of check-in counters. }\end{array}$ & $\begin{array}{l}\text { - total revenue, } \\
\text { - PAX } \\
\text { - ATM, } \\
\text { - cargo+mail. }\end{array}$ \\
\hline
\end{tabular}

Source: Own elaboration.

\section{The Use of EU Funds for the Construction or Modernization of Airports}

In Poland, between 2004 and 2013, with the support of EU funds, 69 projects were implemented, aimed at directly improving the quality of air transport in Poland (National Information System - KSI SIMIK 07-13; www.funduszeeuropejskie.gov.pl). The projects included the construction of new infrastructure elements as well as the extension or modernization of existing ones. In addition, the purchase of equipment necessary for the operation of airports was also included. The co-financing of the projects came from two main streams of aid: Operational Program Infrastructure and Environment (37\% of total expenditure financing) and Regional Operational Programs (42\% of total expenditure financing), and the co-financing was used by all voivodeships within which there are airports, that is, 12 territorial units. The largest number of projects was implemented in Podkarpackie voivodship, while the highest total value was recorded in investments in Masovian voivodeship (Fig.2). It can be presumed that this is due to the fact that the construction of a completely new second airport in Masovian voivodeship, with the simultaneous modernization of the Chopin Airport, was made. However, it was not possible to isolate the funds allocated solely to the construction of the WMI airport. 
Figure: 2

Projects Implemented in 2007-2013 in Airports with the Support of EU Funds by Voivodeships and the Number and Value of Investments

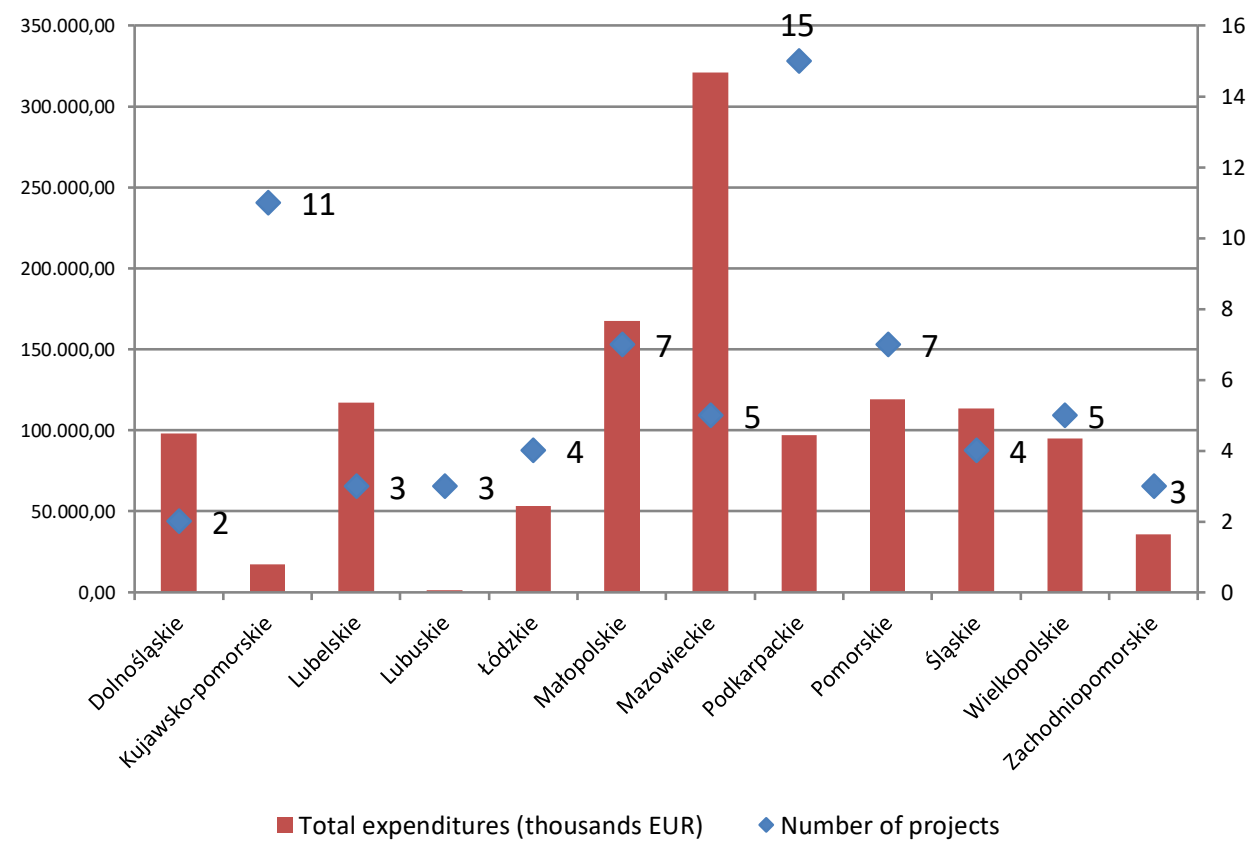

Source: own calculation based on data of the National Information System (KSI SIMIK 07-13).

In case of project co-financing (Fig.3), the highest rate was achieved by works in the IEG airport in Lubuskie Voivodeship, but it should be noted that, among all the analysed units, the overall value of the projects for the IEG airport was the lowest (Fig.2). The lowest co-financing rate in the total value of projects was recorded in Masovian voivodeship. 
Figure: 3

\section{Share of Project Co-Financing in Airports in Total Expenditure in 2004-2013}

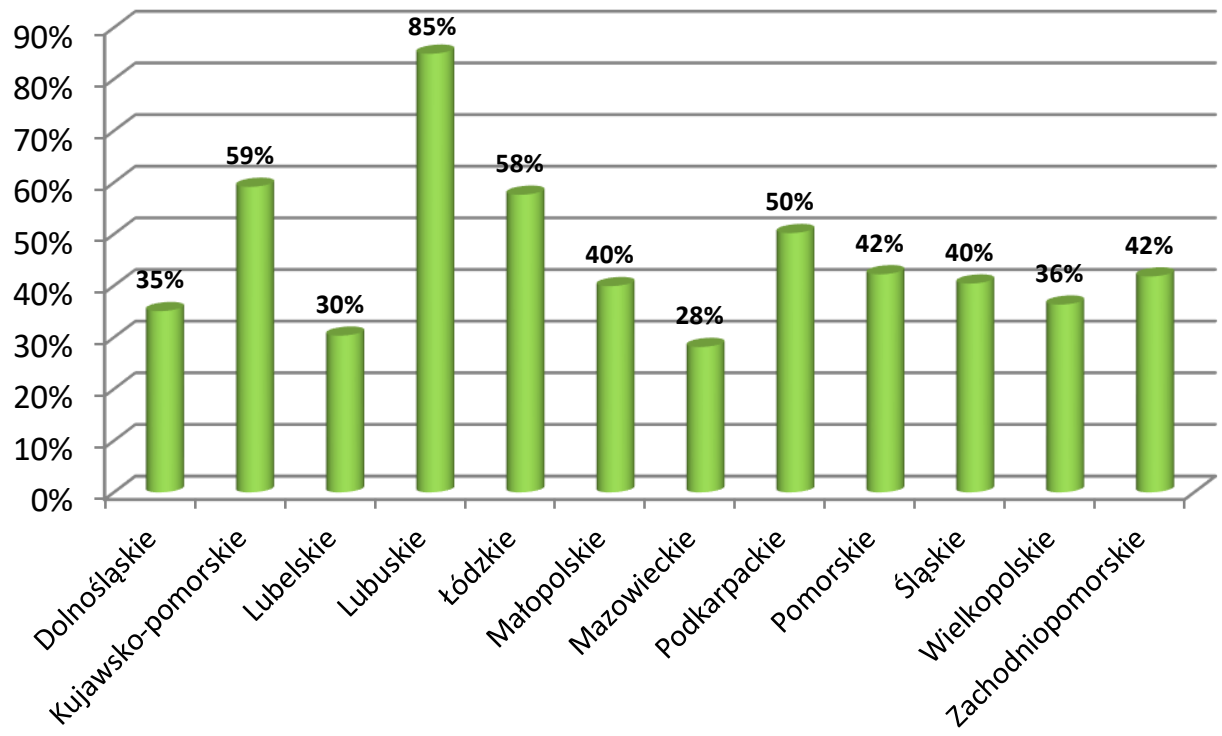

Source: own calculation based on data of the National Information System (KSI SIMIK 07-13).

\section{Efficiency of the Use of Structural Funds in Airports}

The output-oriented BCC model was used to determine the efficiency of investments in individual airports. The model orientated to maximizing effects was adopted since it was assumed that the invested own funds and foreign funds should result in as many effects as possible. The following variables were used for the calculated DEA model:

- input $\mathrm{x}_{1}$ - the total value of funds allocated for investments in 2004-2013,

- effect $\mathrm{y}_{1}$ - increase in the number of passengers served between 2004 and 2013,

- effect $\mathrm{y}_{2}$ - increase in performed airport operations (ATM) in the years 2007-2013,

- effect $y_{3}$ - increase in the number of parking aprons in the years 2004-2013,

- effect $\mathrm{y}_{4}$ - increase in the number of direct regular destinations directly operated by aircrafts in the years 2004-2013,

- effect $y_{5}$ - increase in the number of gates in the years 2004-2013. 
In the first stage of the research, the efficiency of the investments made in individual airports was recognized and the airport ranking was calculated according to the investment efficiency index (see Figure 4).

The average DEA efficiency index for the examined group of airports was quite high - 0.87. Six of the twelve airports can be considered as efficient investment (using funds), their efficiency index was 1 . In the group of efficient DMU there are the following airports: Poznań-Ławica, Kraków, Katowice, Gdańsk, Szczecin-Goleniów, Zielona Góra - Babimost (figure 4). The efficiency index for other airports ranged from 0.32 to 0.98 . The lowest efficiency of the investment was observed in the case of the Rzeszów-Jasionka airport.

In the next phase of the research, based on the DEA method for inefficient DMUs, optimum technologies were identified that would increase their efficiency to unity. According to the idea of benchmarking for airports with ineffective investments, benchmarks were defined. On the basis of these patterns for ineffective airports, a combination of technologies was designed to achieve greater effects using a given level of investment outlay. The calculations were based on the values of the linear combination coefficients of the common technology $-\lambda$ (Table 2).

Figure: 4

Efficiency of Investment in Polish Airports

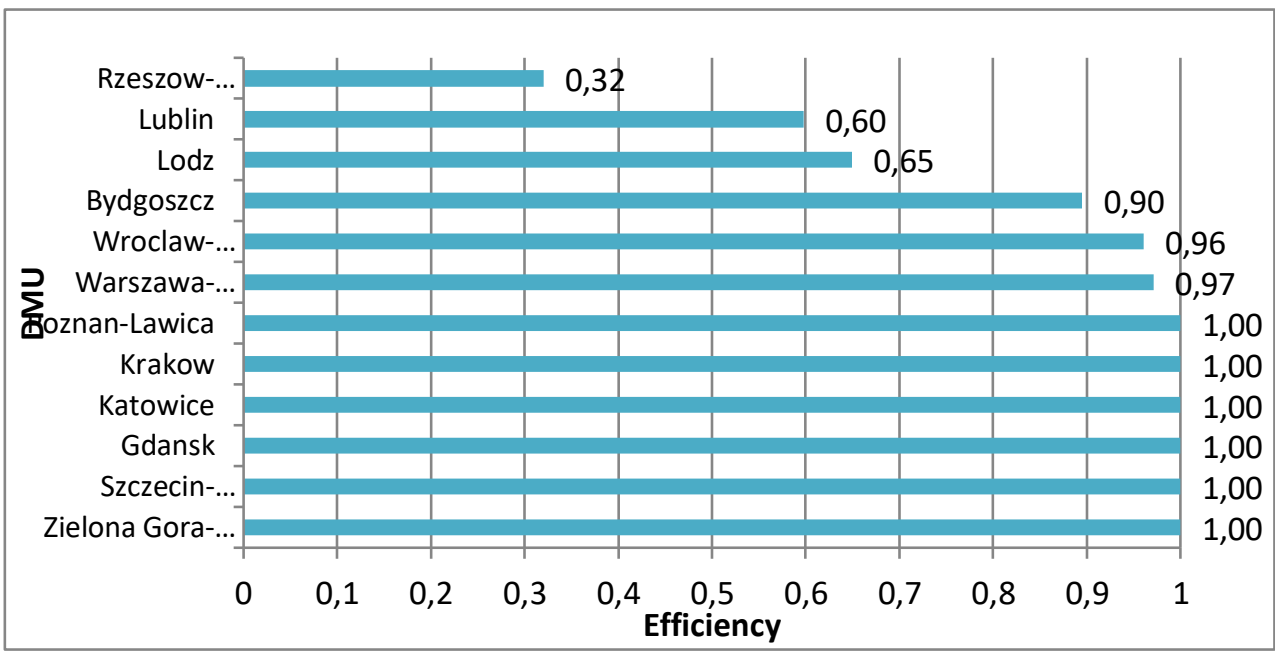

Source: own calculation. 
Table: 2

\section{Linear Combination Coefficients $(\lambda)$ of Technology Common to Airports}

\begin{tabular}{|c|c|c|c|c|c|}
\hline \multirow{2}{*}{ DMU (inefficient airports) } & \multicolumn{5}{|c|}{ Efficient airports - benchmarks } \\
\hline & Gdańsk & Katowice & Zielona Góra-Babimost & Poznań - Lawica & Szczecin-Goleniów \\
\hline Bydgoszcz & & 0.144 & 0.856 & & \\
\hline Lublin & 0.687 & 0.311 & & 0.002 & \\
\hline Łódź & 0.205 & & & 0.002 & 0.793 \\
\hline Rzeszów-Jasionka & 0.212 & 0.633 & 0.155 & & \\
\hline Warszawa-Modlin & 0.219 & 0.696 & & 0.065 & 0.020 \\
\hline Wrocław-Strachowice & 0.428 & 0.414 & 0.157 & & \\
\hline
\end{tabular}

Source: own research.

For example, for inefficient Warsaw-Modlin airport, Gdańsk, Katowice, PoznańŁawica and Szczecin-Goleniów airports (fully efficient) became benchmarks. In other words, in order for the Warsaw-Modlin airport to be considered as an efficient investor, it should be based on the efficiency of investing in the airports that make up its benchmarks. Thus, using the investment expenditures spent in 2007-2013 of PLN 454 million Warsaw Port - Modlin should achieve the following effect size increases: PAX - 2114263; ATM 11429, destinations -31 , parking spaces - 1710, gates - 6.2 (table 3 ).

Suggested effect sizes are above the effect sizes recorded in the Warsaw - Modlin airport. This airport could be included in the efficient investments if, with the amount of invested funds in 2007-2013, it had reached PAX higher by 24\%; ATM by 3\%, 3\% more destinations, $71 \%$ more parking spaces and 3\% more gates.

Table: 3

The Results of the Benchmarking Analysis for Warszawa-Modlin

\begin{tabular}{|c|c|c|c|c|c|c|c|}
\hline & \multicolumn{4}{|c|}{ Benchmarks for Warszawa - Modlin } & \multirow[b]{2}{*}{$\begin{array}{l}\text { Projected output for } \\
\text { Warszawa - Modlin }\end{array}$} & \multirow{2}{*}{$\begin{array}{l}\text { Present level of } \\
\text { Warszawa - } \\
\text { Modlin outputs }\end{array}$} & \multirow{2}{*}{$\begin{array}{l}\text { Estimated } \\
\text { percentage increase } \\
\text { in the outputs of } \\
\text { Warszawa-Modlin }\end{array}$} \\
\hline & Gdańsk & Katowice & $\begin{array}{l}\text { Poznań - } \\
\text { Lawica }\end{array}$ & $\begin{array}{l}\text { Szczecin- } \\
\text { Goleniów }\end{array}$ & & & \\
\hline Output 1 - PAX & 2773408 & 2060622 & 1077330 & 191041 & $\begin{array}{l}0.219 \times 2773408+ \\
0.696 \times 2060622+ \\
0.065 \times 1077330+ \\
0.02 \times 191041=2114263\end{array}$ & 1703743 & $24 \%$ \\
\hline Output 2 - ATM & 1108 & 14966 & 11796 & 172 & $\begin{array}{l}0.219 \times 1108 \\
+0.696 \times 14966+ \\
0.065 \times 11796+0.02 \times 172 \\
=11429\end{array}$ & 11100 & $3 \%$ \\
\hline Output 3 - destinations & 40 & 30 & 17 & 8 & $\begin{array}{l}0.219 \times 40+0.696 \times 30+ \\
0.065 \times 17+0.02 \times 8=31\end{array}$ & 30 & $3 \%$ \\
\hline Output 4 - parking spaces & 222 & 2380 & 0 & 300 & $\begin{array}{l}0.219 \times 222+0.696 \times 2380+ \\
0.065 \times 0+0.02 \times 300= \\
1711\end{array}$ & 1000 & $71 \%$ \\
\hline Output 5 - gates & 7 & 6 & 6 & 4 & $\begin{array}{l}0.219 \times 7+0.696 \times 6+ \\
0.065 \times 6+0.02 \times 4=6.2\end{array}$ & 6 & $3 \%$ \\
\hline $\begin{array}{l}\text { The values of coefficients } \\
\text { of the linear combination } \\
\text { of common technology for } \\
\text { inefficient Warszawa- } \\
\text { Modlin }\end{array}$ & 0.219 & 0.696 & 0.065 & 0.020 & & & \\
\hline
\end{tabular}

Source: own research.

Potential changes that should be made in terms of effects at individual airports are shown in Table 4. The results suggest that, given the investment outlays, inefficient airports should achieve higher effects, which would allow them to improve the efficiency of their investments and change their ranking. The largest changes in all generated effects require airports in Lublin, Lodz and Rzeszow-Jasionka. In the case of Warsaw-Modlin and 
Wroclaw-Starachowice airports it is recommended to increase parking spaces and pax. Bydgoszcz also need to increase all the investment effects but the biggest increase requires number of gates.

Table: 4

Recommendations for Increasing the Effects for Each Airport

\begin{tabular}{|l|r|r|r|r|r|}
\hline DMU & Pax & ATM & Destinations & Parking spaces & Gates \\
\hline Bydgoszcz & $24 \%$ & $12 \%$ & $55 \%$ & $195 \%$ & $1000 \%$ \\
\hline Lublin & $1000 \%$ & $67 \%$ & $426 \%$ & $98 \%$ & $67 \%$ \\
\hline Lódź & $192 \%$ & $54 \%$ & $264 \%$ & $198 \%$ & $54 \%$ \\
\hline Rzeszów-Jasionka & $259 \%$ & $333 \%$ & $212 \%$ & $212 \%$ & $1000 \%$ \\
\hline Warszawa-Modlin & $24 \%$ & $3 \%$ & $3 \%$ & $71 \%$ & $3 \%$ \\
\hline Wrocław-Strachowice & $22 \%$ & $4 \%$ & $4 \%$ & $172 \%$ & $37 \%$ \\
\hline
\end{tabular}

Source: own calculation.

\section{Summary and Conclusions}

Based on the Data Envelopment Analysis method, a ranking of Polish airports was created based on the efficiency of investments conducted in 2007-2013. Six airports were considered to be efficient in using investment outlays (Ławica, Kraków, Katowice, Gdańsk, Szczecin-Goleniów, Zielona Góra - Babimost). For ineffective airports, by benchmarking of facilities, the authors suggested changes to be made at the level of achieved effects that could improve the efficiency of the investment. From the practical point of view it must be underlined that this kind of improvement should not be based on further investments in infrastructure but be focused on "soft" possibilities as encouraging passengers for using the airport, signing the new business contracts with reputable airlines, increasing service quality etc.

It is very difficult to compare our results with the ones of foreign Authors, as the literature is not available as far as we are concerned. It may be also controversial to compare the airport investment efficiency between the countries with the different economic situation, which started expending the terminals in another moment of time. Nevertheless, if it is possible in the future, the implicational aim of these research would be a huge set of information for whole airport industry in Europe.

The DEA airport ranking may, however, be disputable, since the adoption of another variable list could produce other results. This ranking should therefore be seen as an impetus for further research. According to the authors, to evaluate the efficiency of investment, one should use an integrated approach - based on different methods that complement each other and thus allow one to formulate credible conclusions. The efficiency of investment is a complex economic phenomenon, and the methods used to analyse it have their advantages and limitations. Research using other methods and various factors that determine the efficiency of the investment can provide a starting point for proper interpretation and assessment of the efficiency of airport investment, and thus for the search for directions to improve this efficiency. 


\section{References}

Abdesaken, G. \& W. Chen \& A. Cullmann (2006), "The Relative Efficiency of German and British Airports: An Application of Partial Factor Methodology and Data Envelopment Analysis", German Airport Performance, Federal Ministry of Education and Research, Infraday Berlin, October.

Augustyniak, W. (2014), "Efficiency Change in Regional Airports during Market Liberalization", Economics \& Sociology, 7(1), 85-93.

Banker, R.D. \& A. Charnes \& W.W. Cooper (1984), "Some Models for Estimating Technical and Scale Inefficiency in Data Envelopment Analysis", Management Science, 30(9), 10781092.

Charnes, A. \& W.W. Cooper \& A. Rhodes (1978), "Measuring the Efficiency of Decision Making Units", European Journal of Operational Research, 2(6), 429-444.

Coelli, T.J. \& D.S. Prasada Rao \& C.J. O’Donnell \& G.E. Battese (2005), An Introduction to Efficiency and Productivity Analysis, Springer, New York.

Cooper, W.W. \& L.M. Seiford \& K. Tone (2007), Data Envelopment Analysis, A Comprehensive Text with Models, Applications, References and DEA-Solver Software, Kluwer Academic Publishers, New York.

Gillen, D. \& A. Lall (1997), "Developing Measures of Airport Productivity and Performance: An Application of Data Envelopment Analysis", Transportation Research Part E: Logistics and Transportation Review, 33(4), 261-273.

Górecka, A. (2015), "Znaczenie kluczowych inwestycji infrastruktury transportu dla mieszkańców”, in: Pieniak-Lendzieon, A. Marcysiak \& T. Nowogródzka (eds.) Wspótczesny marketing $i$ logistyka - innowacyjne rozwiazania, Unitas, Siedlce, Poland, 542-436.

Martín, J.C. \& C. Román (2001), “An application of DEA to measure the efficiency of Spanish airports prior to privatization”, Journal of Air Transport Management, 7(3), 149-157.

Pacecho, R.R. \& E. Fernades (2002), "Efficient Use of Airport Capacity", Transportation Research Part A: Policy and Practice, 36(3), 225-238.

Pacecho, R.R. \& E. Fernades (2003), "Managerial efficiency of Brazilian Airports", Transportation Research Part A: Policy and Practice, 37(8), 667-680.

Parker, D. (1999), "The performance of BAA Before and after privatization: A DEA Study", Journal of Transport Economics and Policy, 33(2), 133-146.

Salazar de la Cruz, F. (1999), “A DEA approach to the airport production function”, International Journal of Transport Economics, 26(2), 255-270.

Vogel, H.A. (2004), “Airport Privatisation and Performance”, Dissertation, University of Westminster, School of Architecture and the Built Environment.

Yoshida, Y. \& H. Fujimoto (2004), “Japanese-Airport Benchmarking with the DEA and Endogenous-Weight Tfp Methods: Testing the Criticism of Overinvestment in Japanese Regional Airports", Transportation Research Part E: Logistics and Transportation Review, 40(6), 533-546. <www.funduszeeuropejskie.gov.pl>, 30.05.2017. 
Górecka, A. \& J. Baran (2018), "Efficiency of Investments in Regional Airports in Poland", Sosyoekonomi, Vol. 26(38), 23-35. 